\title{
PDLIM3 Gene
}

National Cancer Institute

\section{Source}

National Cancer Institute. PDLIM3 Gene. NCI Thesaurus. Code C118548.

This gene may be involved in cytoskeletal rearrangement. 